\title{
FERTILIZATION WITH LIQUID SWINE MANURE INCREASES PRODUCTIVITY AND IMPROVES THE QUALITY OF Urochloa decumbens
}

\author{
FERTILIZAÇÃO COM DEJETO LÍQUIDO SUÍNO AUMENTA A \\ PRODUTIVIDADE E MELHORA A QUALIDADE DA Urochloa decumbens
}

\author{
Vanderley José PEREIRA; Daniel Ferreira de ASSIS²; Regina Maria Quintão LANAª \\ Adriane de Andrade SILVA ${ }^{4}$; Hamilton Seron PEREIRA \\ 1. Teacher, Doctor, Universidade Federal de Uberlândia - UFU, Monte Carmelo, MG, Brasil. vamceres.vamderley@gmail.com; 2. \\ Teacher, Doctor, Instituto Federal de Educação, Ciência e Tecnologia do Triângulo Mineiro - IFTM, Uberlândia, MG, Brasil; 3. \\ Teacher, Doctor, UFU, Uberlândia, MG, Brasil; 4. Teacher, Doctor, UFU, Monte Carmelo, MG, Brasil; 5. Teacher, Doctor, UFU, \\ Uberlândia, MG, Brasil.
}

\begin{abstract}
This study aims at assessing the influence of mineral fertilization and biofertilizer from liquid swine manure (LSM) in productivity, levels of crude protein (CP), neutral detergent fiber (NDF) and Acid Detergent Fiber (ADF) of Urochloa decumbens. The experiment was carried out in a red Latosol under a Urochloa decumbens pasture, in a state of degradation with loss of vigor and forage productivity. The delineation chosen for this study was randomized blocks with six treatments (control without fertilization, control with use of mineral fertilizer and four unique concentrations of liquid swine manure biofertilizer (61 m3 $\left.\left.\mathrm{ha}^{-1}, 121 \mathrm{~m}^{3} \mathrm{ha}^{-1}, 181 \mathrm{~m}^{3} \mathrm{ha}^{-1}, 241 \mathrm{~m}^{3} \mathrm{ha}^{-1}\right)\right)$. The application of residue has been split in two times on the surface of the soil, by means of a distributor of liquid waste with a fan-shaped application. Yield and bromatological features were evaluated for two years. Fertilization with LSM can fully replace mineral fertilizing in Urochloa decumbens pasture systems, resulting in an increase, as a result, in the dry mass yield from the dosage of $121 \mathrm{~m}^{3} \mathrm{ha}^{-1}$ and the reduction in fiber content in neutral and acid detergent. The increments in yield were observed in the second year, while improvement in bromatological quality was observed from the first application of LSM.
\end{abstract}

KEYWORDS: Brachiaria decumbens. Pasture degradation. Liquid swine manure. Environmental impact. Liquid fertilizer.

\section{INTRODUCTION}

The growing evolution in performance and nutritional improvement indexes of the swine herd places Brazil on a par with its international counterparts, since in the first quarter of 2016 alone $10060 \quad 000$ heads were slaughtered, which represents a $9.6 \%$ increase in comparison with the same period in 2015 (IBGE, 2016). However, this advance also entails issues pertaining the adequacy and environmental licensing of these properties, which may pollute if proper manure treatment systems are not used.

It is widely known that pig farming produces a considerable amount of organic mass, represented primarily by animal waste (SHARMA et al., 2009). The characteristics of swine manure vary according to sex, size, breed and animal activity as well as material management. In addition, such characteristics are also affected by environmental factors such as temperature and air humidity and, yet, the food provided, on the basis of its digestibility, its protein content, fibers, etc. (SHARMA et al., 2015).
Due to all aforementioned factors, intensive animal production farms have been subject to of study; be it in terms of environmental management, new resources for soil fertilization or for the production of new technologies in order to maximize the use of waste. Despite of this fact, the most common practice when it comes to the disposal of the waste produced into anaerobic treatment lagoons. Typically, the final effluent is applied in farming areas as fertilizer, and it often replaces mineral fertilization (CHERUBIN et al., 2015). However, this practice has become an issue due to its imprudent use, since nutrients are spread constantly in the same area exceeding the capacity of extraction by plants, which saturates the soil mainly as far as $\mathrm{P}, \mathrm{Cu}$ and $\mathrm{Zn}$ are concerned (GONZALEZ-FERNANDEZ et al., 2008) and it also contributes to the acidification of the soil (SILVA et al., 2015a). In addition to this damage, other negative effects that swine manure may cause are: emissions of polluting gases, accumulation of heavy metals in soils, pollution of groundwater due to leaching, surface water contamination and the spread of diseases such as cyanosis, worms, 
allergies and hepatitis (SILVA et al., 2015b; SOUZA et al., 2009).

In Mombasa grass (Panicum maximum Jacq.), Freitas et al. (2009) tested the effects of fertilization with LSM $\left(100,150\right.$ and $200 \mathrm{~m}^{3} \mathrm{ha}^{-1}$ year $^{-1}$ ) and mineral fertilizer (NPK) for two consecutive years. For the first year, the yield of the treatments with the swine manure were equivalent to the $\mathrm{N}$-free treatment, which can be explained by slow digestion. In the second year of the assessment, fertilization with LSM at a dose of 100, 150 and 200 $\mathrm{m}^{3} \mathrm{ha}^{-1}$ year $^{-1}$ increased their yield in $234 \%, 280 \%$ and $282 \%$ respectively. Thus, the effect of LSM proves the prolonged effect on nutrient release. This is due to organic mass, which increases $\mathrm{CTC}_{\mathrm{pH}}=7.0$, as well as providing greater soil retention of nutrients and the reduction of losses to the environment.

Therefore, techniques that enable the material disposal of LSM sustainably are relevant. Furthermore, significant nutrient values make LSM a viable alternative as organic fertilizer. Pig farmers do not normally practice fertilization on pastures in the light of the high costs of mineral fertilizers and the low outcome, therefore, LSM configures a reasonable alternative to pasture fertilization in partial or total replacement of mineral fertilization, this fact is supported by an extensive review which reports on the improvement in the physical, chemical and biological characteristics of the soil (CHERUBIN et al., 2015). In this sense, knowing the tolerance and performance of Urochloa decumbens in light of the concentrations of Liquid Swine Manure (LSM) was the aim of this study, as well as enabling the ecologically-correct disposal and sustainable fertilization.

\section{MATERIAL AND METHODS}

The experimental area was installed in a red Latosol (EMBRAPA, 1999), between the Parallels $18^{\circ} 52^{\prime}$ and $18^{\circ} 51^{\prime} 11.3^{\prime} 58.8^{\prime \prime}$ south latitude and the meridians 48 33' $08^{\prime \prime}$ and 48 33' 6.8" west longitude from Greenwich, with an altitude of 800 meters, in the municipality of Uberlandia - state of Minas Gerais. The climate according to Köppen classification is Aw, characterized as rainy tropical, megathermal, with dry winters. The experimental area consisted of pasture with signs of degradation, such as bare soil, presence of termite mounds, invasive plants and low levels of nutrients (table 1), among others.

Table 1. Chemical Characteristics of the profile of degraded soil, cultivated with Urochloa decumbens

\begin{tabular}{|c|c|c|c|c|c|}
\hline \multirow{2}{*}{ 'Determination } & \multicolumn{5}{|c|}{ Depth (cm) } \\
\hline & $0-5$ & $5-10$ & ${ }^{2} 0-10$ & $10-20$ & $20-40$ \\
\hline $\mathrm{pH}$ in $\mathrm{H}_{2} \mathbf{O}$ & 6.2 & 5.8 & 6.5 & 5.5 & 5.5 \\
\hline$P\left(\mathrm{mg} \mathrm{dm}^{-3}\right)$ & 6.2 & 1.3 & 2.9 & 1.3 & 0.9 \\
\hline$K\left(\mathrm{mg} \mathrm{dm}^{-3}\right)$ & 26 & 27 & 32 & 29 & 27 \\
\hline $\mathrm{Al}\left(\mathrm{cmol}_{\mathrm{c}} \mathrm{dm}^{-3}\right)$ & 0.0 & 0.1 & 0.0 & 0.3 & 0.3 \\
\hline $\mathrm{Ca}\left(\mathrm{cmol}_{\mathrm{c}} \mathrm{dm}^{-3}\right)$ & 1.4 & 0.7 & 1.1 & 0.4 & 0.3 \\
\hline $\operatorname{Mg}\left(\mathrm{cmol}_{\mathrm{c}} \mathrm{dm}^{-3}\right)$ & 0.4 & 0.2 & 0.4 & 0.1 & 0.1 \\
\hline $\mathrm{B}\left(\mathrm{mg} \mathrm{dm} \mathbf{~ d m}^{-3}\right)$ & 0.35 & 0.23 & - & 0.26 & 0.31 \\
\hline $\mathrm{Cu}\left(\mathrm{mg} \mathrm{dm}^{-3}\right)$ & 0.5 & 0.7 & - & 0.6 & 0.6 \\
\hline $\mathrm{Fe}\left(\mathrm{mg} \mathrm{dm}^{-3}\right)$ & 40 & 40 & - & 30 & 30 \\
\hline $\operatorname{Mn}\left(\mathrm{mg} \mathrm{dm}^{-3}\right)$ & 3.0 & 5.1 & - & 5.1 & 5.8 \\
\hline $\mathrm{Zn}\left(\mathrm{mg} \mathrm{dm}^{-3}\right)$ & 0.3 & 0.3 & - & 0.2 & 0.2 \\
\hline $\mathrm{S}^{-\mathrm{SO}_{4}}\left(\mathrm{mg} \mathrm{dm}^{-3}\right)$ & 3 & 1 & - & 3 & 7 \\
\hline $\mathrm{H}+\mathrm{Al}\left(\mathrm{cmol}_{\mathrm{c}} \mathrm{dm}^{-3}\right)$ & 2.1 & 2.7 & 1.7 & 2.9 & 2.6 \\
\hline $\mathrm{SB}\left(\mathrm{cmol}_{\mathrm{c}} \mathrm{dm}^{-3}\right)$ & 1.9 & 1.0 & 1.6 & 0.6 & 0.5 \\
\hline$t\left(\mathrm{cmol}_{c} \mathrm{dm}^{-3}\right)^{\prime}$ & 1.95 & 1.09 & 1.56 & 0.89 & 0.77 \\
\hline$T\left(\mathrm{cmol}_{\mathrm{c}} \mathrm{dm}^{-3}\right)$ & 4.02 & 3.73 & 3.22 & 3.49 & 3.06 \\
\hline$V(\%)$ & 48 & 27 & 48 & 17 & 15 \\
\hline M (\%) & 0 & 9 & 0 & 34 & 39 \\
\hline$O M\left(\mathbf{g ~ k g}^{-1}\right)$ & 19 & 15 & 20 & 12 & 8 \\
\hline
\end{tabular}

${ }^{1} \mathrm{P}$ and $\mathrm{K}=\left(\mathrm{HCl} 0.05 \mathrm{~mol} \mathrm{l}^{-1}+\mathrm{H}_{2} \mathrm{SO}_{4} 0.025 \mathrm{~mol} \mathrm{l}^{-1}\right)$; $\mathrm{Al}, \mathrm{Ca}, \mathrm{Mg}=\left(\mathrm{KCl} 1 \mathrm{~mol} \mathrm{l}^{-1}\right)$; $\mathrm{SB}=$ Sum of the bases; $\mathrm{t}=\mathrm{effective} \mathrm{CTC}$; $\mathrm{T}=$ $\mathrm{CTC}$ on $\mathrm{pH} 7.0 ; \mathrm{V}=$ Bases Saturation; $\mathrm{m}=$ Saturation by aluminum; $\mathrm{OM}=$ Organic Matter; $\mathrm{B}=\left[\mathrm{BaCl}_{2} .2 \mathrm{H} 2 \mathrm{O}\right.$ a $0.125 \%$ to hot $]$; $\mathrm{Cu}, \mathrm{Fe}$, $\mathrm{Mn}, \mathrm{Zn}=$ [DTPA $0.005 \mathrm{M}+\mathrm{CaCl} 0 ., 001 \mathrm{M}+$ TEA $0.1 \mathrm{M}$ to $\mathrm{pH} 7.3]$; $\mathrm{S}_{-} \mathrm{SO}_{4}=\mathrm{Ca}\left(\mathrm{H}_{2} \mathrm{PO}_{4}\right)_{2} 0.01 \mathrm{~mol} \mathrm{l}^{-1} ;{ }^{2}$ for this depth, measurements of micro-nutrient and sulphates were not measured. 
The area featured a uniform landscape, with $2 \%$ inclination. This area was chosen due to its sandy soil $(801.3 ; 33.7$ and $165 \mathrm{~g} \mathrm{~kg}$ of the proportions of sand, silt and clay, respectively in the 0 to $20 \mathrm{~cm}$ layer and $771.8 ; 38.4$ and $189.8 \mathrm{~kg}$ of proportions of sand, silt and clay, respectively in the 20 to $40 \mathrm{~cm}$ layer), according to EMBRAPA (1999), as possible problems arising from the leaching of nutrients in the soil profile, and consequently in the plant, are enhanced. The plots were composed of $250 \mathrm{~m}^{2}(25 \times 10 \mathrm{~m})$ and $2 \mathrm{~m}$ were left between plots.

The liquid swine manure used in this study was obtained from Fazenda Simmental da Xapetuba in the municipality of Monte Alegre de Minas Minas Gerais. This compound has been generated by a farm, it was managed in a water system that directs waste for a countinous-stream tubular PVC biodigestor. After the process of anaerobic biodigestion, the biofertilizer remained in a storage pond, from where it was removed for fertilization. The chemical composition of the LSM indicates significant levels of macro and micro-nutrients (table 2). In addition, the $\mathrm{pH}$ was found to be 7.4, with significant organic content $(32.5 \%)$ and carbon and nitrogen (28/1).

Table 2. Physico-chemical characteristics of liquid swine manure

\begin{tabular}{|c|c|}
\hline Determination & Concentration \\
\hline $\mathrm{pH}$ in $\mathrm{CaCl}_{2} 0.01 \mathrm{~mol} \mathrm{~L}^{-1}$ & 7.4 \\
\hline Total Organic Mass (\%) & 32.4 \\
\hline $\mathrm{C} / \mathrm{N}$ ratio & $28 / 1$ \\
\hline Total Nitrogen $\left(\mathrm{mg} \mathrm{L}^{-1}\right)$ & 732 \\
\hline Phosphorus $\left(\mathrm{P}_{2} \mathrm{O}_{5}\right)$ total $\left(\mathrm{mg} \mathrm{L}^{-1}\right)$ & 630.0 \\
\hline Potassium $\left(\mathrm{K}_{2} \mathrm{O}\right)$ total $\left(\mathrm{mg} \mathrm{L}^{-1}\right)$ & 362.0 \\
\hline Calcium (Ca) $\left(\mathrm{mg} \mathrm{L}^{-1}\right)$ & 230.0 \\
\hline Magnesium (Mg) (mg L $\left.{ }^{-1}\right)$ & 103.3 \\
\hline Manganese (Mn) $\left(\mathrm{mg} \mathrm{L}^{-1}\right)$ & 5.418 \\
\hline Copper $(\mathrm{Cu})\left(\mathrm{mg} \mathrm{L}^{-1}\right)$ & 5.208 \\
\hline $\operatorname{Zinc}(\mathrm{Zn})\left(\mathrm{mg} \mathrm{L}^{-1}\right)$ & 14.92 \\
\hline $\operatorname{Iron}(\mathrm{Fe})\left(\mathrm{mg} \mathrm{L}^{-1}\right)$ & 12.4 \\
\hline Boron $(B)\left(\mathrm{mg} \mathrm{L}^{-1}\right)$ & 1.24 \\
\hline Sodium (Na) (mg L $\left.{ }^{-1}\right)$ & 98.0 \\
\hline Total Solids $\left(\mathrm{mg} \mathrm{L}^{-1}\right)$ & 5.046 .0 \\
\hline
\end{tabular}

The delineation used in this study comprised of randomized blocks (DRB) with four repetitions and with six treatments. The treatments were four doses of LSM $\left(61 \mathrm{~m}^{3} \mathrm{ha}^{-1} ; 121 \mathrm{~m}^{3} \mathrm{ha}^{-1} ; 181 \mathrm{~m}^{3} \mathrm{ha}^{-}\right.$ $\left.{ }^{1} ; 241 \mathrm{~m}^{3} \mathrm{ha}^{-1}\right)$, the parcels were cultivated using the conventional method, with mineral fertilization and a control (without any fertilization). In the mineral fertilization treatment, the recommended dosage based on soil texture and technological level was used, for phosphorus (amount of establishment) (CFSEMG, 1999). Therefore, it was applied to the soil of $60 \mathrm{Kg} \mathrm{ha}^{-1} \mathrm{~N}, 75 \mathrm{Kg} \mathrm{ha}^{-1} \mathrm{P}_{2} \mathrm{O}_{5}$ and $100 \mathrm{Kg}$ $\mathrm{ha}^{-1} \mathrm{~K}_{2} 0$. After applying the LSM to the soil surface by means of a liquid waste distributor with a fanshaped application, the pasture was submitted to a resting period of 60 days, during the rainy season. Subsequently, the plots were harvested for assessment, this procedure was repeated for two consecutive years

Dry mass yield was assessed through forage collection of the parcels, according to the methodology for determining the sample year of the predefined area of $0,5 \mathrm{~m}^{2}$, collecting the material at ground level, with a sickle. The samples were placed in paper bags perforated for air circulation, after drying in an oven of forced ventilation at $55^{\circ} \mathrm{C}$ for 72 hours, the dry mass was obtained. Later, the samples were ground in a Willey mill for the bromatological and foliar characterizations.

To determine the crude protein, the quantitative analysis of the total Nitrogen according to Silva (1998) with the Semi-micro Kjeldahl method was carried out. The determination of neutral detergent Fiber (NDF) and Acid Detergent Fiber (ADF) was conducted according to the Van Soest method described by Silva (1998). Statistical analysis of all the features was performed by using the analysis of variance and Tukey test at 5\% probability.

\section{RESULTS AND DISCUSSION}

In the first year of cultivation of Urochloa decumbens, there was no difference between the fertilization (oscillating from $1,264.75$ to 1467.75 $\mathrm{kg} \mathrm{ha}^{-1}$ in the absence and in the dose of $241 \mathrm{~m}^{3} \mathrm{ha}^{-1}$ 
of LSM), however, in the second year, there were increases with the use of LSM (table 3). This lack of variation in the first year was unexpected, because despite the range studied, Urochloa decumbens is characterized by good adaptation to conditions of low fertility and hydric stress, it responds well to fertilization as well as to the rainy season (PEZZOPANE et al., 2015; CAMACHO et al., 2015).

Although it has presented a good rainfall distribution, the effects of the organic matter added to the soil takes some time to be felt due to the humification process of this material in the soil. This can be observed by the productivity difference between the first and second year. The recent application of the material generated a low response in the first year, but it is already possible to observe an increase in productivity with the higher doses of DLS. In the second year, with the accumulated effects of the applications, it is easy to observe an expressive increase in productivity, generating differences between the control treatments, the mineral fertilizer and the lower dose of LSM with the two highest doses of LSM (Table 3).

Table 3. Yield and qualitative characteristics of the first and second year of Urochloa decumbens evaluated at 60 days for both years after fertilization with liquid swine manure and mineral sources

\begin{tabular}{|c|c|c|c|c|c|c|c|c|c|}
\hline \multirow{2}{*}{\multicolumn{2}{|c|}{ Fertilization }} & \multicolumn{4}{|c|}{${ }^{2}$ Yeild $\left(\mathrm{Kg} \mathrm{ha}^{-1}\right)$} & \multicolumn{4}{|c|}{ Neutral detergent fiber $(\%)$} \\
\hline & & \multicolumn{2}{|c|}{$1^{\text {st }}$ year } & \multicolumn{2}{|c|}{$2^{\text {nd }}$ year } & \multicolumn{2}{|c|}{$1^{\text {st }}$ year } & \multicolumn{2}{|c|}{$2^{\text {nd }}$ year } \\
\hline \multirow{2}{*}{\multicolumn{2}{|c|}{$\begin{array}{l}\text { Mineral } \\
\text { Control }\end{array}$}} & 1264.75 & A & 646.50 & B & 79.00 & $\mathrm{C}$ & 79.75 & A \\
\hline & & 150425 & A & 1606.75 & B & 78.25 & $\mathrm{BC}$ & 79.50 & A \\
\hline & 60 & 1225.50 & A & 1212.50 & B & 72.75 & A & 81.00 & A \\
\hline$\sum_{\infty}^{\top}$ & 121 & 1389.00 & A & 1912.50 & $\mathrm{AB}$ & 74.25 & $\mathrm{AB}$ & 73.50 & A \\
\hline$=$ & 181 & 1224.50 & A & 3249.25 & A & 72.75 & A & 77.00 & A \\
\hline & 241 & 1467.75 & A & 3255.75 & A & 78.75 & $\mathrm{C}$ & 76.50 & A \\
\hline \multicolumn{2}{|c|}{$\mathrm{CV} \%$} & \multicolumn{2}{|c|}{31.01} & \multicolumn{2}{|c|}{52.79} & \multicolumn{2}{|c|}{2.31} & \multicolumn{2}{|c|}{6.16} \\
\hline \multicolumn{2}{|c|}{ DMS } & 959.0 & & 220 & & 4. & & & \\
\hline \multirow{2}{*}{\multicolumn{2}{|c|}{ Fertilization }} & \multicolumn{4}{|c|}{ Crude protein $(\%)$} & \multicolumn{4}{|c|}{ Acid detergent fiber (\%) } \\
\hline & & \multicolumn{2}{|c|}{$1^{\text {st }}$ year } & \multicolumn{2}{|c|}{$2^{\text {nd }}$ year } & \multicolumn{2}{|c|}{$1^{\text {st }}$ year } & \multicolumn{2}{|c|}{$2^{\text {nd }}$ year } \\
\hline \multirow{2}{*}{\multicolumn{2}{|c|}{$\begin{array}{l}\text { Mineral } \\
\text { Control }\end{array}$}} & 6.25 & A & 7.25 & A & 44.00 & B & 43.45 & $\mathrm{BC}$ \\
\hline & & 6.00 & A & 7.25 & A & 47.75 & $\mathrm{C}$ & 46.00 & $\mathrm{C}$ \\
\hline & 60 & 5.50 & A & 7.00 & A & 40.00 & A & 38.00 & A \\
\hline$\sum^{\top}$ & 121 & 5.75 & A & 8.25 & A & 40.00 & A & 40.25 & BA \\
\hline${ }^{n}{ }^{n}=$ & 181 & 5.50 & A & 7.25 & A & 40.00 & A & 40.00 & A \\
\hline & 241 & 6.00 & A & 7.75 & A & 40.00 & A & 44.75 & $\mathrm{C}$ \\
\hline \multicolumn{2}{|c|}{ CV\% } & \multicolumn{2}{|c|}{17.24} & \multicolumn{2}{|c|}{10.36} & \multicolumn{2}{|c|}{1.06} & \multicolumn{2}{|c|}{3.45} \\
\hline \multicolumn{2}{|c|}{ DMS } & \multicolumn{2}{|c|}{2.31} & \multicolumn{2}{|c|}{1.77} & \multicolumn{2}{|c|}{1.05} & \multicolumn{2}{|c|}{3.34} \\
\hline
\end{tabular}

${ }^{1} \mathrm{LSM}=$ Liquid Swine Manure; ${ }^{2}$ For each characteristic, the average followed by the same letter in the column do not differ according to Tukey test $(\mathrm{P}<0.05)$

The dosage of $241 \mathrm{~m}^{3} \mathrm{ha}^{-1}$ of LSM in the first year caused a yield increase of $16 \%$ over the absence of fertilization, whereas in the second year, the increase was $503.6 \%$ (table 3). This late behavior of the LSM regarding productivity can be explained by increments in productivity in the first and second harvest when the LSM was used, while these values remained the same with mineral fertilization. This fact is not novel in scientific literature and it is due to the mineralization of organic matter, which provides the plants with $\mathrm{N}$ slowly over a longer period (SERAPHIM; GALBIATTI, 2012; ZAFAR et al., 2012; CARDOSO et al., 2015).

In the second year, doses over $181 \mathrm{~m}^{3} \mathrm{ha}^{-1}$ of LSM were enough to increase production in relation to the control $(\mathrm{P} \leq 0.05$; Table 3$)$. In this year, the presence of an Indian summer may have influenced the treatments; reducing the productivity of the control treatment, but it is easy to observe the benefits of organic fertilization, where even in years of lower rainfall, in the second year, where the DLS was applied, productivity increased. Since the highest dosage of LSM has, accordingly, the highest quantity of water, in addition to nutrients, which culminates in better development of the plant.

The comparison between manure and chemical fertilization should extend also to qualitative characteristics of forage. In this light, Cassol et al. (2011), after six annual applications of

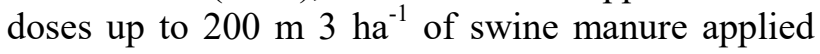
over the ground surface did not cause any difference 
in ph. Unlike the soluble fertilizer containing urea as source of N, the LSM did not make the soil acidic at the depth of $6 \mathrm{~cm}$. Doses from $50 \mathrm{~m}^{3} \mathrm{ha}^{-1}$ of LSM have increased the amount of extractable $\mathrm{K}$ from the soil at depths up to $20 \mathrm{~cm}$ and also increased the levels of extractable $\mathrm{P}, \mathrm{Cu}$ and $\mathrm{Zn}$.

The dry mass yield of grass with LSM was superior to the mineral fertilization (Andrade et al., 2014). In this study, the two highest dosages of LSM alone differed statistically from the treatment with mineral fertilizer (table 3 ).

We had hoped that the application of LSM would result in difference in levels of crude protein, but it could not be verified (table 3). Several factors may have contributed to the lack of response in the accumulation of crude protein, being low nitrogen content present in the bio-fertilizer applied the main factor, added to that is the fact the bio-fertilizer had potential for volatilization after application. In fact, the nitrogen is known to affect growth of grass, mainly in the leaves; However, the effect on the proportion of each component (protein, lipids, etc.) remains poorly understood, especially when the source is organic (LAJÚS et al.., 2014). It seems to be a tendency that the protein levels increase in the presence of an organic source, since the use of swine manure resulted in an increase in crude protein values of Brachiaria decumbens after 35 days of application, even on the lowest dose $\left(60 \mathrm{~m}^{3}\right.$ $\mathrm{ha}^{-1}$ ), but these values were not superior to those of the conventional fertilization (SILVA et al., 2015a). For black oats, the application of LSM to the dose of $50 \mathrm{~m}^{3} \mathrm{ha}^{-1}$ provided an increase in crude protein levels (MONDARDO et al.., 2011). The application of up to $310 \mathrm{~m}^{3} \mathrm{ha}^{-1}$ of LSM in giant-missionary grass (Axonopus jesuiticus) increased the percentage of crude protein, hemicellulose, vascular tissue and unlignified parenchyma, which reduced the percentage of insoluble acid detergent fiber and lignified vascular tissue + sclerenchyma (LAJÚS et al.., 2014).

Protein is the nutritional component that is most required by ruminants. The critical level for the maintenance of activities of rumen cellulolytic bacteria is $7 \%$ of $\mathrm{PB}$ in MS. Below this level, for it does not meet the minimum requirements, microbial growth is limited, which reduces the cell wall digestibility, mass consumption by the animal and, consequently, the animal performance (mass gain). Protein excess promotes excretion of urea via urine (GOES et al., 2015). In the second year, it was observed that in all treatments crude protein levels were higher than the aforementioned level, even in the control treatment, which satisfactorily met the minimum protein requirements for of ruminants (table 3).

Again, o regime hídrico é aquele que deve influenciar esta diferença entre o primeiro e o segundo ano de cultivo. No primeiro ano, sem um efeito ainda satisfatório do DLS lançado associado a uma maior lixiviação de $\mathrm{N}$, o controle de um produto com maior intensidade production between os treatments, but a protein was least to control, demonstrating the effect of diluation due to major growth of plant. Além do nitrogênio, outros nutrientes podem ser potencialmente lixiviados, como a doença, com um forte adsorção pelas colóides do solo, pode ser perdido. Isto é necessário para o $\mathrm{pH}$ da água residuária, favorecendo uma mineralização, aumentando a liberação de $\mathrm{CO} 2 \mathrm{e}$, consequentemente; uma lixiviação de $\mathrm{Ca}$ (HCO3) 2 com água (MAGGI et al., 2011). O segundo ano de cultivo, as pequenas porções de $\mathrm{N}$ foi gerada por um maior teor proteico e o maior teor de proteínas devido a uma maior produtividade.

Different from protein levels, low levels of NDF are desirable and indicate high nutritional quality of the forage, because according to Sandahl et al. (2005), the NDF content of a forage plant was consolidated as the bromatological component more closely related to their potential intake by ruminants. Thus, the lower the levels of this component, the better the quality of the forage produced and the greater the consumption of MS (SANTOS et al., 2010). In this sense, smaller doses of LSM provided the forage with best quality. In the first harvest, smaller doses of LSM smaller levels of provided lower fiber levels (NDF), while the highest dose was similar to conventional fertilization, with NDF superior to $78 \%$ (table 3 ). For the second year, such a difference between fertilizations was not observed.

Fertilization, especially the Nitrogen based, in some cases, reduce the fiber content, and contribute to the improvement of the forage quality (MONDARDO et al.., 2011). The results of this study ratify this hypothesis by pointing out that the highest dose of organic or mineral fertilizer resulted in increased fiber content (table 3). It is known that nitrogen is a modulator in the production of vegetable hormones, which culminate with a higher vegetative development. Thus, providing more nitrogen to the culture caused the plant to grow more and produce more fiber for its support. In alfalfa, this interaction was evident, as the application of gibberellic acid interfered negatively in the levels of protein, according to the cellular elongation, culminating in cellular fill, mainly by water and lignin, and not by solutes, such as proteins (GARCIA et al., 2006). 
According to Mertens (2000) the NDF is the indicator of the total fiber in foods, and knowing them in a plant is important. It is also related to the age of the plant, because the more mature the plant, the higher its NDF fraction and the worse it will be for digestibility and animal gain. The dose increment applied to LSM does not lead to an increase in the levels of ADF in the first year, stable at $40 \%$ and lower than the mineral fertilization as well as the absence of fertilization (table 3 ). In the second year, the highest levels were observed in the control treatment, with mineral fertilization and a higher dosage of LSM (241 m 3 ha-1). As ADF values were lower when fertilized with LSM, in most cases, one can infer that the application of LSM improved fiber characteristics. LSM increases the nitrogen and potassium supply to the soil, which promotes plant growth and favors the increase in the leaf/stem ratio (larger amount of NDF (cellulose) and more ADF (lignin)) (SERAPHIM; GALBIATTI, 2012), Consequently improving the digestibility of forage (MANN et al., 2007; SERAPHIM; GALBIATTI, 2012). An addendum is relevant at this point, either for ADF or ND, LSM decreased those levels and, when it did not change, it increased protein levels.

\section{CONCLUSION}

Fertilization with liquid swine manure can fully replace mineral fertilizing in the pasture system of Urochloa decumbens, increasing productivity of dry mass from the dosage of $121 \mathrm{~m}^{3}$ $\mathrm{ha}^{-1}$ and reducing fiber content in neutral and acid detergents. The increments in productivity were observed in the second year, while quality improvement was observed from the first application of liquid swine manure.

RESUMO: Objetivou-se avaliar a influência da fertilização mineral e do biofertilizante de dejeto líquido suíno (DLS) na produtividade, teores de Proteína Bruta (PB), Fibra em Detergente Neutro (FDN) e Fibra em Detergente Ácido (FDA) da Urochloa decumbens. O experimento foi desenvolvido em um Latossolo vermelho sob pastagem de Urochloa decumbens, em estado de degradação evoluída com perda de vigor e produtividade da forrageira. O delineamento utilizado foi em blocos casualizados com seis tratamentos (controle sem fertilização, controle com uso de fertilizante mineral e quatro concentrações exclusivas de biofertilizante de dejeto líquido suíno $\left.\left(61 \mathrm{~m}^{3} \mathrm{ha}^{-1}, 121 \mathrm{~m}^{3} \mathrm{ha}^{-1}, 181 \mathrm{~m}^{3} \mathrm{ha}^{-1}, 241 \mathrm{~m}^{3} \mathrm{ha}^{-1}\right)\right)$. A aplicação do resíduo foi parcelada em duas vezes na superfície do solo, por meio de um distribuidor de resíduos líquidos com a aplicação em leque. Foram avaliadas por dois anos a produtividade, e as caracterizações bromatológica foliares. A fertilização com DLS pode substituir integralmente a fertilização mineral no sistema de pastejo de Urochloa decumbens, aumentando a produtividade de massa seca a partir da dosagem de $121 \mathrm{~m}^{3} \mathrm{ha}^{-1}$ e redução no teor de Fibras em detergente neutro e ácido. Os incrementos na produtividade foram observados no segundo ano, ao passo que melhoria na qualidade gramatológicas foi observada a partir da primeira aplicação do DLS.

PALAVRAS-CHAVES: Brachiaria decumbens. Degradação da pastagem. Dejeto líquido suíno, Fertilizante líquido. Impacto ambiental

\section{REFERENCES}

AGUIAR, A. P. A. Possibilidades de intensificação do uso da pastagem através de rotação sem ou com uso mínimo de fertilizantes. In: SIMPÓSIO SOBRE MANEJO DE PASTAGEM, 14. 1999, Piracicaba. Anais... Piracicaba: Fundação de Estudos Agrários "Luiz de Queiroz", 1999. p.37-40.

ANAMI, M. H.; SAMPAIO, S. C.; SUSZEK, M.; GOMES, S. D.; DE QUEIROZ, M. M. F. Deslocamento miscível de nitrato e fosfato proveniente de água presidiária da suinocultura em colunas de solo. Revista Brasileira de Engenharia Agrícola e Ambiental, v.12, n.1, p.75-80, 2008. http://dx.doi.org/10.1590/S141543662008000100011

ANDRADE, A. S.; DRUMOND, L. C. D.; RABELO, D. M. L.; APPELT, M. F.; LIMA, J. C. L.; OLIVEIRA, V. M. R. de. Crescimento de gramíneas forrageiras fertirrigadas com água residuária de suinocultura. Revista Trópica: Ciências Agrárias e Biológicas, v.8, n.2, 2014.

http://www.periodicoseletronicos.ufma.br/index.php/ccaatropica/article/view/1122 
BARNABÉ, M. C.; BENEVAL, R.; LOPES, E. L.; ROCHA; G. P.; FREITAS, K. R. Produção e composição químico-bromatológica da Brachiaria brizantha cv. marandu adubada com dejetos líquidos de suínos. Ciência Animal Brasileira, v.8, n.3, p.435-446, 2007. https://www.revistas.ufg.br/vet/article/view/1681 14 Jul. 2017.

BURTON, G. W. Registration of Tifton 78 Bermuda grass. Crop Science, Madison, v. 28, p.187-188, 1998. https://www.researchgate.net/profile/Roger_Gates2/publication/250116221_Registration_of_\%27Tifton_85\%2 7_Bermudagrass/links/54ff7ab70cf2741b69f84a9f/Registration-of-Tifton-85-Bermudagrass.pdf

CAMACHO, M. A.; SILVEIRA, L. P. O.; SILVEIRA, M. V.; CAMACHO, M. A.; SILVEIRA, L. P. O.; SILVEIRA, M. V. Eficiência de genótipos de Brachiaria brizantha Stapf. (Syn: Urochloa brizantha) na produção de biomassa sob aplicação de fósforo. Arquivo Brasileiro de Medicina Veterinária e Zootecnia, v.67, n.4, p.1133-1140, 2015. http://dx.doi.org/10.1590/1678-4162-6763

CASSOL, P. C.; SILVA, D. C. P.; ERNANI, P. R.; FILHO, O. K.; LUCRÉCIO, W. Chemical attributes of a South Brazilian Oxisol fertilized with swine manure and soluble fertilizer. Revista de Ciências Agroveterinárias (Journal of Agroveterinary Sciences), v.0, n.2, p.103-112, 2011. http://revistas.udesc.br/index.php/agroveterinaria/article/view/5273/3483

CHERUBIN, M.R.; EITELWEIN, M.T.; FABBRIS, C.; WEIRICH, S.V.; SILVA, R.F.; SILVA, V.R.; BASSO, C.J. Qualidade física, química e biológica de um latossolo com diferentes manejos e fertilizantes. Revista Brasileira de Ciências do Solo. v.39, p.615-625, 2015. http://dx.doi.org/10.1590/01000683rbcs20140462.

COMISSÃO DE FERTILIDADE DO SOLO DO ESTADO DE MINAS GERAIS (CFSEMG).

Recomendações para o uso de corretivos e fertilizantes em Minas Gerais: $5^{\text {a }}$ Aproximação, Belo Horizonte: EPAMIG, 1999, 180p.

DURIGON, R.; CERETTA, C.A.; BASSO, C.J. Produção de forragem em pastagem natural com o uso de esterco líquido de suínos. Revista Brasileira de Ciência do Solo, v.26, p.983-992, 2002.

http://dx.doi.org/10.1590/S0100-06832002000400016.

EMPRESA BRASILEIRA DE PESQUISA AGROPECUÁRIA (EMBRAPA). Sistema Brasileiro de Classificação de Solos. Brasília: Embrapa produções de informações/Rio de Janeiro: Embrapa Solos, 1999, 412p.

FREITAS, K. R.; ROSA, B.; NASCIMENTO, J. L. do; BARBOSA, M. M.; ROCHA, L. O. da; SANTOS, S. C. Avaliação da produção de massa seca e atributos químicos de solos com capim-mombaça submetido à fertilização orgânica, mineral e irrigação.Bioscience Journal, v.25, n.3, p.141-150, 2009.

http://www.seer.ufu.br/index.php/biosciencejournal/article/view/6938/4597.

GARCIA, R. R. Efeito de reguladores vegetais no desenvolvimento de plantas de alfafa (Medicago sativa L.) cv. Crioula. Marília - SP: UNIMAR, 2006. 41p. (Monografia). http://www.secam.unimar.br/pos/trabalhos/arquivos/168fbd2fa3ac845ee9b4779013fcca70.pdf

GASPARI, P.; C., SANTOS, P.M.; CRUZ, P.G.; ALTOÉ, J.; RIBEIRO, F.A.; VALLE, C.B. Estresse por deficiência hídrica em genótipos de Brachiaria brizantha. Ciência Rural, v.45, n.5, p.871-876, 2015. http://dx.doi.org/10.1590/0103-8478cr20130915.

GOES, R.H.T.B.1; GANDRA, J.R.; MARQUEZ, A.F.; OLIVEIRA, E.R.; FERNANDES, H.J.; CARDOSO, T.J. DE L.; BRABES, K.C.S.; YOSHIHARA, M.M. Metabolismo nitrogenado em bovinos suplementados a pasto durante a transição águas

seca. Revista Archivos de Zootecnia, v.64, p.281-290, 2015. http://dx.doi.org/10.21071/az.v64i247.399. 
GONZALEZ-FERNANDEZ, C.; NIETODIEZ, P.; LEONCOFRECES, C.; GARCIAENCINA, P. Solids and nutrients removals from the liquid fraction of swine slurry through screening and flocculation treatment and influence of these processes on anaerobic biodegradability. Bioresource Technology, v.99, n.14, p.6233-6239, 2008. Https://doi.org/10.1016/j.biortech.2007.12.022.

KONZEN, E.A. Fertilização de lavoura e pastagem com dejetos de suínos e cama de aves. Sete Lagoas: Embrapa Milho e Sorgo, 2003. 3p. (Embrapa Milho e Sorgo. Circular técnica, 31).

LAJÚS, C.R.; MIRANDA, M.; BASSO, S.M.S.; CARNEIRO, C.M.; ESCOSTEGUY, P.A.V. Proporção de tecidos foliares e composição química de Axonopus jesuiticus $\mathrm{x}$ A. scoparius em função da aplicação de dejeto líquido de suíno. Ciência Rural, v.44, n.2, p.276-282, 2014. http://dx.doi.org/10.1590/S010384782013005000154.

LUCAS JR, J. Algumas considerações sobre o uso do estrume de suínos como substrato para três sistemas de biodigestores anaeróbios. Tese de Livre-Docência. Faculdade de Ciências Agrárias e Veterinárias, Universidade Estadual Paulista, Jaboticabal, 1994. 137p.

MAGGI, C. F.; FREITAS, P. S. L. de; SAMPAIO, S. C.; DIETER, J. Lixiviação de nutrientes em solo cultivado com aplicação de água residuária de suinocultura. Revista Brasileira de Engenharia Agrícola e Ambiental, v.15, n.2, p.170-177, 2011. http://www.scielo.br/pdf/rbeaa/v15n2/v15n02a10.

MEDEIROS, L.T.; REZENDE, A.V.; VIEIRA, P.F.; CUNHA NETO, F.R.; VALERIANO, A.L.; CASALI, A.O. GASTALDELLO JUNIOR, A.L. Produção e qualidade da forragem de capim-marandu fertilizada com dejetos líquidos de suínos. Revista Brasileira de Zootecnia, v.36, n.2. p.309-318, 2007.

http://dx.doi.org/10.1590/S1516-35982007000200006.

MERTENS, D.R. FDN fisicamente efetivo e seu uso na formulação de rações para vacas leiteiras. In.: TEIXEIRA, J.C.; SANTOS, R.A.; DAVID, S.M. et al. (Eds.) Simpósio internacional de bovinocultura de leite - novos conceitos em nutrição. 2, 2001, SIMLEITE. Anais... Lavras: UFLA/FAEPE, 2001. p.37-49

MOFFITT, D. Waste management and recycling of organic matter. CIGR Handbook of Agricultural Engineering, Animal Production and Aquacultural Engineering. St. Joseph, ASAE, p. 163, 1999.

MONDARDO, D.; CASTAGNARA, D.D.; OLIVEIRA, P.S.R; ZOZ, T.; MESQUITA, E.E. Produção e composição químico-bromatológica da aveia preta fertilizada com doses crescentes de dejeto líquido suíno. Revista Ciência Agronômica, v.42, n.2, p.509-517, 2011.

http://ccarevista.ufc.br/seer/index.php/ccarevista/article/view/1087/599.

OLIVEIRA, P.P.A.; BOARETTO, A.E.; TRIVELIN, P.C.O. Liming and fertilization for restoring degraded Brachiaria decumbens pasture on sandy soil. Scientia Agricola, v.60, n.1, p.125-131, 2003. http://dx.doi.org/10.1590/S0103-90162003000100019.

OLIVEIRA, R.A. de. Sludge bed characteristics of UASB reactors: growth, activity, microbial structure and chemical composition of granules. In.: International Conference on Anaerobic Digestion. Sendai. Proceedings...Sendai: IAWQ/JSWE, 1997, p.524-31.

ROBERTO, C.C.D.S.P.; MÜHLBACH, F.; PERES, L.M.B.S.D.; LIMA, N.L.D. Composição química e digestibilidade 'in vitro' de silagens de milho com distintos teores de umidade e níveis de compactação. Ciência Rural, v.35, n.6, p.1393-1399, 2005. http://dx.doi.org/10.1590/S0103-84782005000600026.

SANTOS, R.D.; PEREIRA, L.G.R.; NEVES, A.L.A.; ARAÚJO, G.G.L.; VOLTOLINI, T.V.; BRANDÃO, L.G.N.; ARAGÃ̃, A.S.L., DÓREA, J.R.R. Características de fermentação da silagem de seis variedades de milho indicadas para a região semiárida brasileira. Arquivo Brasileiro de Medicina Veterinária, Belo Horizonte, v.62, n.6, p.1423-1429, 2010. http://dx.doi.org/10.1590/S0102-09352010000600019. 
SEGANFREDO. A. M. Análise dos riscos de poluição do ambiente, quando se usa dejetos de suínos como fertilizante do solo. Concórdia: EMBRAPA - CNPSA, 2000. Comunicado Técnico.

SERAFIM, R.S.; GALBIATTI, J.A Efecto de la aplicación de la agua residual porcina en el pasto Brachiaria brizantha cv marandu. Revista Colombiana de Ciencia Animal, v.4, n.1, p.185-203, 2012. http://revistas.unisucre.edu.co/index.php/recia/article/view/307/349.

SILVA, A.D.A.; LANA, Â M.Q.; LANA, R.M.Q.; COSTA, A.M.DA; SILVA, A.D. A.; Fertilização com dejetos suínos: influência nas características bromatológicas da Brachiaria decumbens e alterações no solo. Engenharia Agrícola, v.35, n.2, p.254-265, 2015a. http://dx.doi.org/10.1590/1809-4430Eng.Agric.v35n2p254-265/2015.

SILVA, R. A.; VIEIRA, É.N.R.; SANTANA, H.C.; CASTRO, M.F. de; MIRANDA, J.H.R. Impactos ambientais causados pelo uso irregular de dejetos de suínos no solo. ANAIS SIMPAC, v 2, n.1, p.1-5, 2015b. https://academico.univicosa.com.br/revista/index.php/RevistaSimpac/article/view/317/480

SOUZA, C.D.F.; CARVALHO, C.C.S.; CAMPOS, J.A.; MATOS, A.T.; FERREIRA, W.P.M. Caracterização de dejetos de suínos em fase de terminação. Ceres, v.56, n.2, p. 128-133, 2009.

http://www.ceres.ufv.br/ojs/index.php/ceres/article/view/3409/1296

VAN SOEST, P. J. Nutritional ecology of the ruminant. 2. ed. Ithaca: Cornell University Press, 1994. 446p.

VON SPERLING, M. Introdução à qualidade das águas e ao tratamento de esgotos. 2. ed. Belo Horizonte, Departamento de Engenharia Sanitária e Ambiental - Universidade Federal de Minas Gerais. 1996. 243p.

WERNER, J. C. Importância da interação solo-planta-animal na nutrição de ruminantes. In: Curso de atualização em nutrição animal, v. 1, 1993. Brasília: MAARA/SDR/SENA. Anais... Brasília, 1993. p.11-20. 